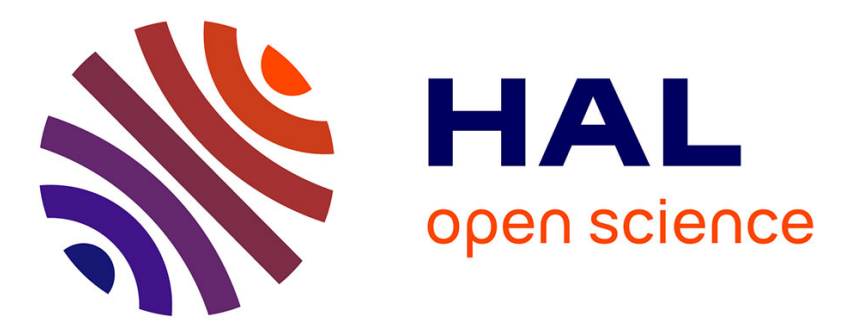

\title{
Confirmatory method for the determination of various acetylgestagens in animal kidney fat using liquid chromatography tandem mass spectrometry
}

Edward Malone, Geraldine Dowling, Chris Elliott, David Glenn Kennedy, Liam Regan

\section{To cite this version:}

Edward Malone, Geraldine Dowling, Chris Elliott, David Glenn Kennedy, Liam Regan. Confirmatory method for the determination of various acetylgestagens in animal kidney fat using liquid chromatography tandem mass spectrometry. Food Additives and Contaminants, 2009, 26 (05), pp.672-682. 10.1080/02652030802642110. hal-00577354

\section{HAL Id: hal-00577354 \\ https://hal.science/hal-00577354}

Submitted on 17 Mar 2011

HAL is a multi-disciplinary open access archive for the deposit and dissemination of scientific research documents, whether they are published or not. The documents may come from teaching and research institutions in France or abroad, or from public or private research centers.
L'archive ouverte pluridisciplinaire HAL, est destinée au dépôt et à la diffusion de documents scientifiques de niveau recherche, publiés ou non, émanant des établissements d'enseignement et de recherche français ou étrangers, des laboratoires publics ou privés. 


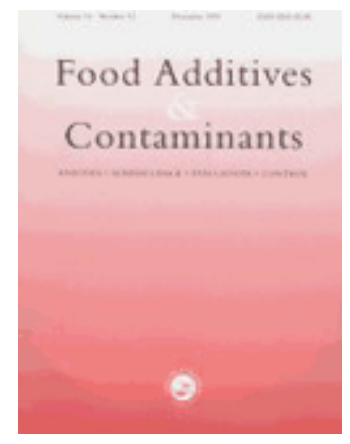

\section{Confirmatory method for the determination of various acetylgestagens in animal kidney fat using liquid chromatography tandem mass spectrometry}

\begin{tabular}{|r|l|}
\hline Journal: & Food Additives and Contaminants \\
\hline Manuscript ID: & TFAC-2008-294.R1 \\
\hline Manuscript Type: & Original Research Paper \\
\hline Date Submitted by the \\
Author: & $19-$ Nov-2008 \\
\hline & $\begin{array}{l}\text { Complete List of Authors: } \\
\text { Malone, Edward; The State Laboratory, Veterinary Toxicology } \\
\text { Elliott, Chris; Queens University, Belfast, School of Biological } \\
\text { Kennedy, David; Chemical Surveillance Branch, VSD, AFBI } \\
\text { Regan, Liam; The State Laboratory, Veterinary Toxicology }\end{array}$ \\
\hline Methods/Techniques: & Extraction, LC/MS, Method validation \\
\hline Additives/Contaminants: & $\begin{array}{l}\text { Drug residues - hormones, Veterinary drug residues - anabolic } \\
\text { steroids, Veterinary drugs }\end{array}$ \\
\hline Food Types: & Animal, Animal products - meat, Oils and fats \\
\hline & \\
\hline
\end{tabular}

\section{SCHOLARONE" Manuscripts}


Confirmatory method for the determination of various acetylgestagens in animal kidney fat using liquid chromatography tandem mass spectrometry

Edward Malone ${ }^{\mathrm{a}, \mathrm{b}}$, Geraldine Dowling ${ }^{\mathrm{a}}$ Chris Elliott ${ }^{\mathrm{b}}$, Glenn Kennedy ${ }^{\mathrm{c}}$, and Liam Regan ${ }^{a}$

${ }^{a}$ The State Laboratory, Backweston, Celbridge, Co. Kildare, Ireland

${ }^{b}$ School of Biological Sciences, Queen's University, Belfast, Northern Ireland ${ }^{c}$ Agri-Food and Bioscience Institute, Belfast, Northern Ireland

\begin{abstract}
A confirmatory method has been developed and validated that allows for the simultaneous detection of medroxyprogesterone acetate (MPA), megestrol acetate (MGA), melengestrol acetate (MLA), chlormadinone acetate (CMA) and delmadinone acetate (DMA) in animal kidney fat using liquid chromatography tandem mass spectrometry (LC-MS/MS). The compounds were extracted from kidney fat using acetonitrile, defatted using a hexane wash and subsequent saponification. Extracts were then purified on Isolute ${ }^{\mathrm{TM}} \mathrm{CN}$ solid phase extraction cartridges and analysed by LC-MS/MS. The method was validated in animal kidney fat in accordance with the criteria defined in Commission Decision 2002/657/EC. The decision limit (CC $\alpha$ ) was calculated to be $0.12,0.48,0.40,0.63$ and $0.54 \mu \mathrm{g} \mathrm{kg}^{-1}$, respectively, for MPA, MGA, MLA, DMA and CMA detection capability (CC $\beta$ ) values of $0.20,0.81,0.68,1.07$ and $0.92 \mu \mathrm{g} \mathrm{kg}^{-1}$ respectively, were obtained.
\end{abstract}


The measurement uncertainty of the method was estimated at 16, 16, 19, 27 and $26 \%$ for MPA, MGA, MLA, DMA and CMA respectively. Fortifying kidney fat samples ( $n=18)$ in three separate assays, show the accuracy of the method to be between 98 and $100 \%$. The precision of the method, expressed as \% RSD values for the withinlab reproducibility at the three levels of fortification $\left(1,1.5\right.$ and $2 \mu \mathrm{g} \mathrm{kg}^{-1}$ for MPA, 5, 7.5 and $10 \mu \mathrm{g} \mathrm{kg}^{-1}$ for MGA, MLA, DMA and CMA) was less than $5 \%$ for all analytes.

Keywords: Acetylgestagens; Kidney Fat; Mass Spectrometry; Decision Limit; Detection Capability

\section{Introduction}

Under European Union (EU) Council Directive 96/22/EC (Council Directive EC 96/22 1996), any substances exhibiting, thyreostatic, androgenic, oestrogenic or gestagenic effects are prohibited for use in food producing animals. The synthetic progestagens, medroxyprogesterone acetate (MPA), megestrol acetate (MGA), melengestrol acetate (MLA), chlormadinone acetate (CMA) and delmadinone acetate (DMA) exhibit gestagenic effects when animals are treated with these substances and are prohibited for use in animals reared for human consumption. Incidents of the illegal administration of gestagens have been previously reported in several European countries (Rapp et al. 1989; Vanoosthuyze et al. 1994).

The acetylgestagen group of compounds exhibit lipophilic properties and hence are more likely to bio-accumulate in fatty, adipose tissues (Krzeminski et al. 1981]. 
Therefore the preferred matrix when testing for these compounds is usually kidney fat as it offers the greatest chance of detecting residues after illegal administration.

In order to maintain a zero tolerance policy with regards to these compounds suitably sensitive analytical methods are required. Low limits of detection are required especially for MPA as it has a minimum required performance level (MRPL) set by the EU at $1 \mu \mathrm{g} \mathrm{kg}^{-1}$ in porcine kidney fat (Commission Decision 2003/181 2003). There is no MRPL set for MGA, MLA, CMA and DMA. However laboratories should be capable of monitoring at levels of $5 \mu \mathrm{g} \mathrm{kg}^{-1}$ which is the required performance level (RPL) set by the community reference laboratory (CRL Guidance Paper 2007).

Various analytical methods exist that describe the analysis of gestagens in kidney fat, a wide array of extraction techniques have been applied for this purpose. They include solid phase extraction (SPE) (Lohmus et al 2007, Impens et al 2002, Impens et al 2003, Hageleit et al 2001); supercritical fluid extraction (SFE) (Stolker et al 2002), accelerated solvent extraction (ASE) (Hooijerink et al 2003) and matrix solid phase dispersion (MSPD) (Rosen et al 1994). A rigorous clean-up is required when analysing for these compounds. Hexane wash steps as well as saponification have been described previously in the literature in order to remove some of the lipophilic interferences (Impens et al 2003, Lohmus et al 2007). Other purification techniques used include SPE, which often occurs after hexane washing and/or saponification (Impens et al 2003, Lohmus et al 2007), various types of cartridge chemistry are utilised to achieve. These include $\mathrm{C}_{18}$ (Daeseleire et al 1998, Hooijerink et al 2003, Hageleit et al 2001), Silica+ $\mathrm{NH}_{2}$ (Impens et al 2003) and CN cartridges (Impens et al 
2003). A number of analytical techniques have been published for the determination of acetylgestagens compounds; these include enzyme linked immunoassay (ELISA) (Daxenberger et al 1999), gas chromatography-mass spectrometry (GC-MS) (Impens et al 2002; Impens et al 2003; Stolker et al 1998; Daeseleire et al 1998, Daeseleire et al 1994) and liquid chromatography-mass spectrometry (LC-MS) (Stolker et al 2002, Hooijerink et al 2003, Lohmus et al 2007, Mortensen et al 2007). Other matrices have also been investigated and there is published work on a variety of these. These include the analysis of MPA in bovine hair (Rambaud et al. 2005). Methods have been described to detect gestagens in injection sites that utilise high performance thin layer chromatography (HPTLC) and detection under UV light at $366 \mathrm{~nm}$ and GC-MS (Daeseleire et al 1994). Work on the analysis of gestagens in bovine muscle using high performance liquid chromatography (HPLC) clean-up and fractionation followed by GC-MS analysis has also been published (Daeseleire et al 1998). Methods have been described that analyse gestagens from liver and muscle using GC-MS (Marchand et al 2000) and from bovine and porcine plasma using LC-MS/MS (Mortensen et al 2007) and from skin and meat by GC-MS (Stolker et al 1998).

For Group A substances, mass spectrometry is one of the techniques deemed to provide sufficient confirmatory data under Commission Decision 2002/657/EC (Commission Decision 2002/657/EC 2002). LC-MS has an advantage over GC-MS analysis in the analysis of acetylgestagens as this mode of detection avoids the time consuming and often non robust step of having to hydrolyze and derivatise samples prior to analysis. 
The first aim of this work was to develop a multi-residue LC-MS/MS confirmatory method. This method should be capable of simultaneously identifying and quantifying five acetylgestagen compounds in kidney fat of bovine, ovine, porcine and equine species. The method should be validated according to Commission Decision 2002/657/EC. and establish a measurement of uncertainty for the analytical method developed. The second aim of the work was to accredit the method according to the IS0 17025 standard (ISO/IEC 17025 2005). A third aim was to implement the method into the National Monitoring Plan in Ireland to monitor for misuse of these substances under the requirements of Council Directive 96/23/EC (Council Directive EC 96/23 1996).

The developed method was based on previously published work (Impens et al 2003). It was modified to reduce the analytical sample size required, to include the analysis of delmadinone acetate, to extend the range of species it is applicable to and replace detection using GC-MS/MS with LC-MS/MS.

\section{Materials and methods}

Materials and reagents

Water, methanol, ethyl acetate, acetonitrile and n-hexane, all (HPLC grade) were obtained from BDH (Merck, UK). Magnesium chloride, sodium hydroxide and ammonium acetate, all Analar grade were obtained from BDH (Merck, UK). MPA, MGA, MLA, CMA (Vetranal analytical standards) were obtained from Riedel de Haen (Sigma Aldrich, Ireland). DMA, MPA-d3, MGA-d3, MLA-d3 were obtained from RIVM (Bilthoven, The Netherlands). Primary stock standard solutions of MPA, MGA, MLA and CMA were prepared in methanol at a concentration of $1 \mathrm{mg} \mathrm{mL}^{-1}$. 
Primary stock standard solutions of the deuterated internal standards as well as DMA were prepared by reconstitution of ampoules containing $0.1 \mathrm{mg}$ with $1 \mathrm{~mL}$ of methanol yielding a concentration of $0.1 \mathrm{mg} \mathrm{mL}^{-1}$. Stock standard solutions with a concentration of $1 \mathrm{mg} \mathrm{mL}^{-1}$ were stored in the dark at less than $-20^{\circ} \mathrm{C}$ until use, up to a period of 12 months. A final working solution containing all the analytes, except internal standards, was prepared in methanol at a concentration of $300 \mathrm{ng} \mathrm{mL}^{-1}$ (for MGA, MLA, CMA and DMA) and $60 \mathrm{ng} \mathrm{mL}^{-1}$ (MPA) solutions of all analytes (stable for 6 months). A final internal standard working solution was prepared in methanol at a concentration of $600 \mathrm{ng} \mathrm{mL}^{-1}$ (stable for 6 months). All standards were stored at $20^{\circ} \mathrm{C}$ in the dark. Isolute ${ }^{\mathrm{TM}} \mathrm{CN}$ solid phase extraction cartridges $(6 \mathrm{~mL}, 500 \mathrm{mg})$ were obtained from Biotage (Biotage, UK).

\section{LC conditions}

The LC system consisted of a model Finnigan TSQ Quantum Ultra (MS) coupled to a Finnigan Surveyor LC Pump and a Finnigan Surveyor Autosampler (Thermo Electron Corporation, CA, USA). A gradient LC system (Table 1) using $0.5 \mathrm{mM}$ ammonium acetate:methanol (70:30, v/v Mobile phase A) and $0.5 \mathrm{mM}$ ammonium acetate:methanol $\left(5: 95, \mathrm{v} / \mathrm{v}\right.$ Mobile phase B) at a flow of $0.300 \mathrm{~mL} \mathrm{~min}^{-1}$, was used to separate the analytes on a Phenomenex Luna $3 \mu \mathrm{m} \mathrm{C}_{18}(100$ x $2.0 \mathrm{~mm})$ (Phenomenex, UK) column equipped with a Phenomenex Luna $3 \mu \mathrm{m} \mathrm{C}_{18}$ guard column $(10.0 \times 2.0$ mm I.D.). The column temperature was maintained at $45{ }^{\circ} \mathrm{C}$. Data acquisition and integration were performed using XCalibur version 1.4 chromatographic management software (Thermo Electron Corporation, CA, USA). A linear gradient (Table 1) was used, the total runtime was $28 \mathrm{~min}$. 


\section{MS/MS parameters}

The analysis was performed using electrospray ionization operated in positive polarity and data was gathered using multiple reaction monitoring (MRM) mode. Two transitions per compound were monitored (one transition for the internal standards) and the collision voltages were optimised as shown (Table 2). The MS/MS detector conditions were as follows: Ion mode ESI+; sheath gas pressure 60 psi; auxiliary gas pressure 30 psi; capillary temperature $350{ }^{\circ} \mathrm{C}$; source CID $-10 \mathrm{~V}$; collision pressure 1.5 torr; collision gas argon.

\section{Kidney fat samples}

Bovine, porcine, ovine and equine kidney fat samples were received at our laboratory within $24 \mathrm{~h}$ of animal slaughter for testing as part of the National Residue Control Plan. The samples are stored at $-20{ }^{\circ} \mathrm{C}$ until analysis. Kidney fat ran in previous batches and found to contain no detectable residues of MPA, MGA, MLA, DMA or CMA was used as negative control material.

\section{Sample extraction and clean-up}

A fat tissue sample (approximately $10 \mathrm{~g}$ ) sliced into very fine pieces was transferred into a small glass funnel previously packed with glass wool; this funnel was then placed into a conical flask. This was then placed for at least three hours into an oven $\left(65^{\circ} \mathrm{C}\right)$. A portion $(3 \mathrm{~g})$ of the molten fat is then weighed into a polypropylene centrifuge tube $(15 \mathrm{~mL}), 50 \mu \mathrm{L}$ of the mixed internal standard is added at this time, corresponding to a concentration of $10 \mu \mathrm{g} \mathrm{kg}^{-1}$. Samples are fortified at levels corresponding to 5, 7.5 and $10 \mu \mathrm{g} \mathrm{kg}^{-1}$ for MGA, MLA, CMA, DMA and 1, 1.5 and 2 $\mu \mathrm{g} \mathrm{kg}^{-1}$ for MPA by adding 50,75 and $100 \mu \mathrm{L}$ portions of a $300 \mathrm{ng} \mathrm{mL}^{-1}$ solution of 
MGA, MLA, CMA, DMA and $60 \mathrm{ng} \mathrm{mL} \mathrm{mL}^{-1}$ solution of MPA. After fortification, samples are held for $15 \mathrm{~min}$ prior to extraction. Acetonitrile $(8 \mathrm{~mL})$ is added and the samples are placed into the oven to allow the fat to become molten again and hence mix the acetonitrile. After 15 minutes the samples are removed from the oven and shaken vigorously (30 seconds). They are then centrifuged $\left(3500 \mathrm{rpm}, 10 \mathrm{~min}, 4{ }^{\circ} \mathrm{C}\right)$ and the supernatant is transferred to a clean polypropylene tube. The sample pellet is re-extracted with acetonitrile $(8 \mathrm{~mL})$ using the same procedure as above and the supernatants are combined and dried under nitrogen with heat $\left(55{ }^{\circ} \mathrm{C}\right)$ to an approximate volume of $7 \mathrm{~mL}$. $\mathrm{N}$-hexane $(5 \mathrm{~mL})$ is then added to the samples and they are shaken $(1 \mathrm{~min})$ and centrifuged $\left(3500 \mathrm{rpm}, 10 \mathrm{~min}, 4{ }^{\circ} \mathrm{C}\right)$. The upper hexane layer is then removed and discarded and the acetonitrile extracts are evaporated to dryness under nitrogen with heat $\left(55^{\circ} \mathrm{C}\right)$. The extract is then reconstituted in n-hexane $(5 \mathrm{~mL})$ and vortexed $(1 \mathrm{~min})$, the saponification step is then carried out by the addition of 0.1 M sodium hydroxide $(\mathrm{NaOH})(1.4 \mathrm{~mL})$ followed by of $1 \mathrm{M}$ magnesium chloride $\left(\mathrm{MgCl}_{2}\right)(850 \mu \mathrm{L})$ This is then shaken gently (30 seconds) and placed in an oven (60 $\left.{ }^{\circ} \mathrm{C}\right)$ to aid saponification. The samples are then removed and centrifuged (3500 rpm, $10 \mathrm{~min}, 4{ }^{\circ} \mathrm{C}$ ), the upper hexane layer is then removed and transferred to a clean $15 \mathrm{ml}$ glass test tube.

\section{Solid Phase Extraction}

The sample extracts are purified by SPE using Isolute CN SPE cartridges. Sample extracts are loaded under gravity onto the cartridges (preconditioned with ethyl acetate $(3 \mathrm{~mL})$ and $\mathrm{n}$-hexane $(5 \mathrm{~mL})$. The cartridges are then eluted $(2 \times 2.5 \mathrm{~mL})$ with ethyl acetate :n-hexane $(90: 10, \mathrm{v} / \mathrm{v})$. The eluates are then evaporated to dryness under 
nitrogen with heat $\left(55^{\circ} \mathrm{C}\right)$ and reconstituted in Mobile Phase A $(200 \mu \mathrm{L})(70: 300.5$ $\mathrm{mM}$ ammonium acetate: methanol), vortexed (1 min) and transferred to LC vials.

\section{Matrix-Matched Calibration}

Matrix matched calibration curves were prepared and used for quantification. Control kidney fat previously tested and shown to contain no residues was prepared as above (2.4). One kidney fat sample is used for each calibration standard level. Samples were fortified at levels corresponding to $0,0.5,1,2,3,4$ and $8 \mu \mathrm{g} \mathrm{kg}^{-1} \mathrm{MPA}$ and $0,2.5,5$, 10, 15, 20 and $40 \mu \mathrm{g} \mathrm{kg}^{-1}$ MGA, MLA, DMA, CMA by adding 0, 25, 50, 100, 150, 200 and $400 \mu \mathrm{L}$ portions of a $300 \mathrm{ng} \mathrm{mL}^{-1}$ standard solution of MGA, MLA, DMA, CMA and $60 \mathrm{ng} \mathrm{mL}^{-1}$ of MPA. After fortification, samples were held for 15 min prior to the extraction procedure as described above (2.5). Calibration curves were prepared by plotting the response factor (area of the analyte/area of internal standard) as a function of analyte concentration ( 0 to $8 . \mu \mathrm{g} \mathrm{kg}^{-1}$ for MPA) and (0 to $40 . \mu \mathrm{g} \mathrm{kg}^{-1}$ for MGA, MLA, DMA and CMA) to quantify samples.

\section{Method validation}

For estimation of accuracy, blank kidney fat samples were fortified with MGA, MLA, DMA and CMA at 5, 7.5 and $10 \mu \mathrm{g} \mathrm{kg}^{-1}$ which is $1,1.5$ and 2 times the (RPL) of $5 \mu \mathrm{g} \mathrm{kg}^{-1}$ set for these compounds by the Community Reference Laboratory and fortified with MPA at $1,1.5$ and $2 \mu \mathrm{g} \mathrm{kg}^{-1}$ which is $1,1.5$ and 2 times the (MRPL) set by the EU. Six replicate test portions, at each of the three fortification levels, were analysed. Analysis of the 18 test portions was carried out on three separate occasions. For the estimation of the precision of the method, repeatability and within-laboratory reproducibility was calculated. The decision limit $(\mathrm{CC} \alpha)$ of the method was calculated 
according to the calibration curve procedure using the intercept (value of the response factor, $\mathrm{y}$, where the concentration, $\mathrm{x}$ is equal to zero) and 2.33 times the standard error of the intercept for a set of data with 6 replicates at 3 levels. The detection capability (CC $\beta$ ) was calculated by adding 1.64 times the standard error to the $\mathrm{CC} \alpha$.

\section{Results and Discussion \\ Preliminary experiments:-}

The LC-MS/MS method was developed to provide confirmatory data for the analysis of animal kidney fat for MPA, MGA, MLA, DMA and CMA. An excellent response was noted for each of the analytes using electrospray ionisation in positive polarity and this was the chosen ionization mode for this work. The MS/MS fragmentation conditions were investigated and collision energies were optimised, the fragmentation patterns observed were similar to those found in previously published work (Hooijerink et al. 2003; Mortensen et al. 2007). For a method to be deemed confirmatory in accordance with Commission Decision 2002/657/EC four identification points are required. These identification points are obtained by monitoring one precursor ion and two transition products (corresponding to strong and weak ion transitions). The precursor and product transitions for each of the acetylgestagen compounds assayed for are listed in Table 2 as well as their associated collision energy.

The extraction and sample purification steps in the method described in this paper are based on those described in a previously published work by (Impens et al 2003). However in this paper we have downscaled the sample size from 5 grams to 3 grams, included an extra analyte, delmadinone acetate as well as extended the method to also 
include ovine and equine species. The determination step described in this work is carried out by LC-MS/MS as opposed to GC-MS/MS (Impens et al 2003) and yields lower $\mathrm{CC} \alpha$ and $\mathrm{CC} \beta$ values for all of the analytes examined.

MPA, MGA, MLA, DMA and CMA were chromatographed on a Phenomenex Luna $\mathrm{C}_{18}, 100 \times 3 \mathrm{~mm}, 3 \mu \mathrm{m}$ column, with retention times of $18.5,18.2,18.6,17.7$ and 18.3 min respectively. Deuterated analogues of MPA, MLA and MGA were used as internal standards for these compounds. It was found also that MLA-d3 corrected best for CMA and that MGA-d3 was best at correcting for DMA so these were chosen as their corresponding internal standards. chlormadinone ${ }^{37} \mathrm{Cl}$ acetate was obtained, in order to be used as an I.S. for chlormadinone acetate. However during development it was noted that in samples only fortified with the various I.S. compounds that quite a large response was found in the chlormadinone acetate trace that originated from chlormadinone ${ }^{37} \mathrm{Cl}$ acetate, hence it was decided to omit using this as an internal standard.

\section{Validation study}

Validation of the method was according to procedures described in Commission Decision 2002/657/EC covering specificity, calibration curve linearity, recovery (accuracy), precision, decision limit $(\mathrm{CC} \alpha)$ and detection capability $(\mathrm{CC} \beta)$.

\section{Specificity}

The technique of LC-MS/MS itself offers a high degree of selectivity and specificity. To establish the selectivity/specificity of the method, a variety of fat samples from different species (bovine, ovine, porcine and equine) were fortified with MPA, MGA, 
MLA, DMA and CMA (to check if any of these compounds give rise to peaks for transitions for any of the other analytes, also the data obtained was used in calculating the measurement of uncertainty) and their non-fortified equivalent samples were also analysed. No interfering peaks were observed at the retention time for any of the analytes (Figure 1). Additionally samples were fortified with a variety of steroidal compounds including $\alpha$ and $\beta$ trenbolone, diethylstilbestrol, dienestrol, hexestrol, dexamethasone, betamethasone, flumethasone, methylboldenone, methyltestosterone and fluoxymesterone. No interferences were observed in the retention windows of MPA, MGA, MLA, DMA and CMA in chromatograms when fortified with these substances.

\section{Linearity of the response}

The linearity of the chromatographic response was tested with matrix matched curves using 7 calibration points in the concentration range of 0 to $40 \mu \mathrm{g} \mathrm{kg}^{-1}$ for MGA, MLA, DMA and CMA and 0 to $8 \mu \mathrm{g} \mathrm{kg}^{-1}$ for MPA. The regression coefficients $\left(r^{2}\right)$ for all the calibration curves used in this study were $\geq 0.997$. A plot of residuals was also carried out to further demonstrate the linearity of the response. For each observed value of $\mathrm{x}$ (concentration), the residual is the observed y value (response factor) minus the corresponding fitted $\mathrm{Y}$. The residual was then plotted against the concentration; this is shown in Figure 3 for each of the five analytes. The residuals were acceptable, they have a random scatter rather than any systematic pattern and also they are normally distributed with an approximate mean of zero.

\section{Accuracy}


The accuracy of the method was determined using kidney fat samples fortified at 5.0, 7.5 and $10.0 \mu \mathrm{g} \mathrm{kg}^{-1}$ for MGA, MLA, DMA and CMA and $1,1.5$ and $2 \mu \mathrm{g} \mathrm{kg}^{-1}$ for MPA. The resulting values were calculated from matrix matched calibration curves. Mean corrected recovery $(n=18)$ of the analyte, determined in three separate assays (Table 3) was between 98 and $100 \%$ for MPA, MGA, MLA, DMA and CMA.

\section{Precision}

The usefulness of suitable isotopically labelled internal standards is demonstrated in the excellent repeatability and within-laboratory reproducibility obtained for MPA, MGA and MLA (Table 3). No deuterated analogue was available for CMA or DMA, however these compounds are structurally very similar to the other gestagen compounds which had deuterated analogues, so these internal standards also worked very well for CMA and DMA. In the case of CMA, MLA-d3 was used as the corresponding internal standard and in the case of DMA, MGA-d3 was used as the corresponding internal standard. The precision of the method, expressed as RSD values for the within-lab reproducibility at the three levels of fortification $(5.0,7.5$ and $10.0 \mu \mathrm{g} \mathrm{kg}^{-1}$ for MGA, MLA, DMA and CMA and $1,1.5$ and $2 \mu \mathrm{g} \mathrm{kg}^{-1}$ for MPA) was less than $6 \%$.

\section{$C C \alpha$ and $C C \beta$}

The decision limit is defined as the limit above which it can be concluded with an error probability of $\alpha$, that a sample contains the analyte. In general, for prohibited substances an $\alpha$ value equal to $1 \%$ is applied. The detection capability is the smallest content of the substance that may be detected, identified and quantified in a sample, with a statistical certainty of $1-\beta$, were $\beta=5 \%$. CC $\alpha$ and $\mathrm{CC} \beta$ were calculated using 
the intercept (value of the signal, $y$, were the concentration, $x$ is equal to zero) and the standard error of the intercept for a set of data with 6 replicates at 3 levels on three separate days (5.0, 7.5 and $10.0 \mu \mathrm{g} \mathrm{kg}^{-1}$ for MGA, MLA, DMA and CMA and 1, 1.5 and $2 \mu \mathrm{g} \mathrm{kg}^{-1}$ ). Blank kidney fat was fortified at $1,1.5$ and 2 times the minimum required performance level of $1 \mu \mathrm{g} \mathrm{kg}^{-1}$ for MPA and $5 \mu \mathrm{g} \mathrm{kg}^{-1}$ for MGA, MLA, DMA and CMA. CC $\alpha$ is the concentration corresponding to the intercept +2.33 times the standard error of the intercept. CC $\alpha$ values of $0.12,0.48,0.40,0.54$ and $0.63 \mu \mathrm{g}$ $\mathrm{kg}^{-1}$ were achieved for MPA, MGA, MLA, CMA and DMA respectively. CC $\beta$ is the concentration corresponding to the signal at $\mathrm{CC} \alpha+1.64$ times the standard error of the intercept (i.e the intercept +3.97 times that standard error of the intercept). CC $\beta$ values of $0.20,0.81,0.68,0.92$ and $1.07 \mu \mathrm{g} \mathrm{kg}{ }^{-1}$ were achieved for MPA, MGA, MLA, CMA and DMA respectively.

\section{Measurement Uncertainty}

The measurement of uncertainty was estimated by taking into account the within laboratory reproducibility over days 1,2 and 3 as well as considering the repeatability on day 4 due to matrix effects caused by different species (bovine, ovine, porcine and equine) and different animals. These two variability's were combined and multiplied by a coverage factor of three to give an overall figure for the uncertainty of the measurement. This approach of using the within laboratory reproducibility as a good estimator of measurement of uncertainty is taken from the SANCO/2004/2726rev1 document (SANCO 2004/2726rev1 2004). It recommends using the within laboratory reproducibility and using a coverage factor of 2.33 to estimate expanded uncertainty, however as it was felt that not all the environmental and other factors that could be varied over the course of the validation were examined, it was felt that a coverage 
factor of 2.33 may underestimate the true uncertainty of the method. So a value of 3 was chosen instead to give a more realistic value for the true uncertainty, this approach was acceptable to the ISO17025 (ISO/IEC 17025 2005) auditors as well.

\section{Evaluation}

The method developed in this study has been used to monitor for the presence of MPA, MGA, MLA, CMA and DMA residues in kidney fat of bovine, porcine, ovine and equine kidney fat as part of the National Monitoring Plan in Ireland in some of, 2007 and all of 2008. The method has been carried out by different analysts over a period of two years under varying environmental conditions and the method was shown to be robust. The method has been accredited by the Irish National Accreditation Board in accordance with ISO17025 standard which is the main internationally recognised standard used by testing and calibration laboratories. Samples of incurred porcine kidney fat received from the Community Reference Laboratory (CRL), RIVM, Bilthoven, The Netherlands as part of a proficiency scheme. Figure 4 shows a chromatogram with both strong and weak transitions for MPA for one of these incurred kidney fat samples of at a measured concentration of $1.2 \mu \mathrm{g} \mathrm{kg}^{-1}$. These samples were tested using the method described here and were found to yield satisfactory results. In two samples containing incurred MPA, the described method was able to detect and confirm its presence and also the calculated concentrations were close to the CRL's assigned values. In fact when the method's measurement of uncertainty is applied, the assigned values falls within the possible range of concentrations given by this method, no z-scores for this proficiency scheme have been released by the CRL yet. Also the described method found no detectable peaks in the negative control sample sent by the CRL. 


\section{Conclusions}

The aim of this work was to develop, validate and accredit a multi-residue LCMS/MS confirmatory method that can simultaneously identify and quantify five acetylgestagen compounds in kidney fat of bovine, ovine, porcine and equine species. This goal was successfully met and the developed method has been successfully utilised as part of the National Residue Control Plan in the Republic of Ireland. It also has been accredited by the Irish National Accreditation Board to ISO17025 standard and been successfully used in analysing proficiency test samples.

The obtained data fulfils the requirements laid down in Commission Decision 2002/657/EC and allows the calculation of all relevant performance characteristics. This study shows that the developed method meets the required sensitivity of $1 \mu \mathrm{g} \mathrm{kg}-$ ${ }^{1}$ which is the MRPL set by the EU for MPA, and also meets the recommended concentration level of $5 \mu \mathrm{g} \mathrm{kg}^{-1}$ set by the CRL for the other acetylgestagen compounds. The CC $\alpha$ and $\mathrm{CC} \beta$ values determined for each analyte are considerably lower than these levels. The method performs very well in terms of accuracy and repeatability for each of the analytes due to the utilisation of different deuterated internal standards. The values achieved for accuracy (\%), RSD (\%) and measurement of uncertainty (\%) all fall within acceptable ranges. The applicability of the method for use on different species (bovine, ovine, porcine and equine) was demonstrated by the satisfactory results obtained from day 4 and also ongoing data gathered as part of National Residue Monitoring Plan in Ireland for all the different species mentioned previously. 


\section{Acknowledgements}

This work was funded by The State Laboratory, Co. Kildare in Ireland. The authors would like to thank the staff at The State Laboratory, Co. Kildare for their practical assistance.

\section{References}

Commision Decision 2002/657/EC of 12 August 2002 implementing Council Directive 96/23/EC concerning the performance of analytical methods and the interpretation of results. Off. J. Eur. Commun. L2218.

Commission Decision 2003/181/EC of 13 March 2003 amending Decision 2002/657/EC as regards the setting of minimum required performance limits (MRPLs) for certain residues in food of animal origin. Off. J. Eur. Commun. L7117.

Council Directive 96/22/EC. 1996. Concerning the prohibition on the use in stockfarming of certain substances having a hormonal or thyrostatic action and of Bagonists. Off. J Eur Commun. L 125.

Council Directive 96/23/EC. 1996. On measures to monitor certain substances and residues thereof in live animals and animal products. Off. J. Eur. Commun. L221.

CRL Guidance Paper (7 December 2007) CRLs view on state of the art analytical methods for national residue control plans.

Daeseleire E, Vandeputte R, Van Peteghem C. 1998. Validation of multi-residue methods for the detection of anabolic steroids by GC-MS in muscle tissues and urine samples from cattle. Analyst (123) 2595-2598.

Daeseleire E, Vanoosthuyze K, Van Peteghem C. 1994 Application of highperformance thin-layer chromatography and gas chromatography-mass spectrometry 
to the detection of new anabolic steroids used as growth promotors in cattle fattening. J. of Chromatogr. A (674) 247-253.

Daxenberger A, Meyer K, Hageleit M, Meyer HHD. 1999. Detection of melengestrol acetate residues in plasma and edible tissues of heifers. Vet. Quart. (21) 154-157.

General requirements for the competence of testing and calibration laboratories 2005 . ISO/IEC 17025:2005 (E)

Guidelines for the implementation of Commission Decision.. 2002/657/EC. 2004. SANCO/2004/2726rev1.

Hageleit M, Daxenberger A, Meyer HHD. 2001. A sensitive enzyme immunoassay (EIA) for the determination of melengestrol acetate (MGA) in adipose and muscle tissues. Food Addit. Contam. (18) 285-291.

Hooijerink H, van Bennekom EO, Nielen MWF. 2003 Screening for gestagens in kidney fat using accelerated solvent extraction and liquid chromatography electrospray tandem mass spectrometry. Anal. Chim. Acta (483) 51-59.

Impens S, Courtheyn D, De Wasch K. 2003 Faster analysis of anabolic steroids in kidney fat by downscaling the sample size and using gas chromatography-tandem mass spectrometry. Anal. Chim. Acta (483) 269-280.

Impens S, De Wasch K, Cornelius M, De Brabander HF. 2002. Analysis on residues of estrogens, gestagens and androgens in kidney fat and meat with gas chromatography-tandem mass spectrometry. J. Chromatogr A (970) 235-247.

Joos PE, Van Ryckeghem M. 1999. Liquid chromatography-tandem mass spectrometry of some anabolic steroids. Anal. Chem. (71) 4701-4710.

Krzeminski LF, Cox BL, Gosline RE. 1981. Fate of radioactive melengestrol acetate in the bovine. J. Agric. Food Chem. (29) 387-391. 
Rambaud L, Bichon E, Cesbron N, Andre F, Le Bizec B. 2005 Study of 17-estradiol3-benzoate, 17-methyltestosterone and medroxyprogesterone acetate fixation in bovine hair. Anal. Chim. Acta (532) 165-176.

Rapp M, Meyer HHD. 1989. Control of illegal Medroxyprogesterone acetateapplication in veal calves by residue analysis in adipose tissues using HPLC/RIA method. Food Addit. Contam. (6) 59-70.

Rosen J, Hellenas KE, Tornqvist P, Shearan P. 1994 Automated extraction of acetylgestagens from kidney fat by matrix solid phase dispersion. Analyst (119) 26352638.

Stolker AAM, Zoontjes PW, Schwillens PLWJ, Kootstra PR,van Ginkel LA, Stephany RW, Brinkman UATh. 2002. Determination of acetyl gestagenic steroids in kidney fat by automated supercritical fluid extraction and liquid chromatography iontrap mass spectrometry. Analyst (127) 748-754.

Stolker AAM, Zoontjes PW, van Ginkel LA. 1998. The use of supercritical fluid extraction for the determination of steroids in animal tissues. Analyst (123) 26712676. 
Vanoosthuyze K, Daeseleire E, Van Overbeke A, Van Peteghem C. 1994. Survey of the hormones used in cattle fattening based on the analysis of Belgian injection sites. Analyst. (119) 2655-2658. 


1
2
3
4
5
6
7
8
9
10
11
12
13
14
15
16
17
18
19
20
21
22
23
24
25
26
27
28
29
30
31
32
33
34
35
36
37
38
39
40
41
42
43
44
45
46
47
48
49
50
51
52
53
54
55
56
57
59
60
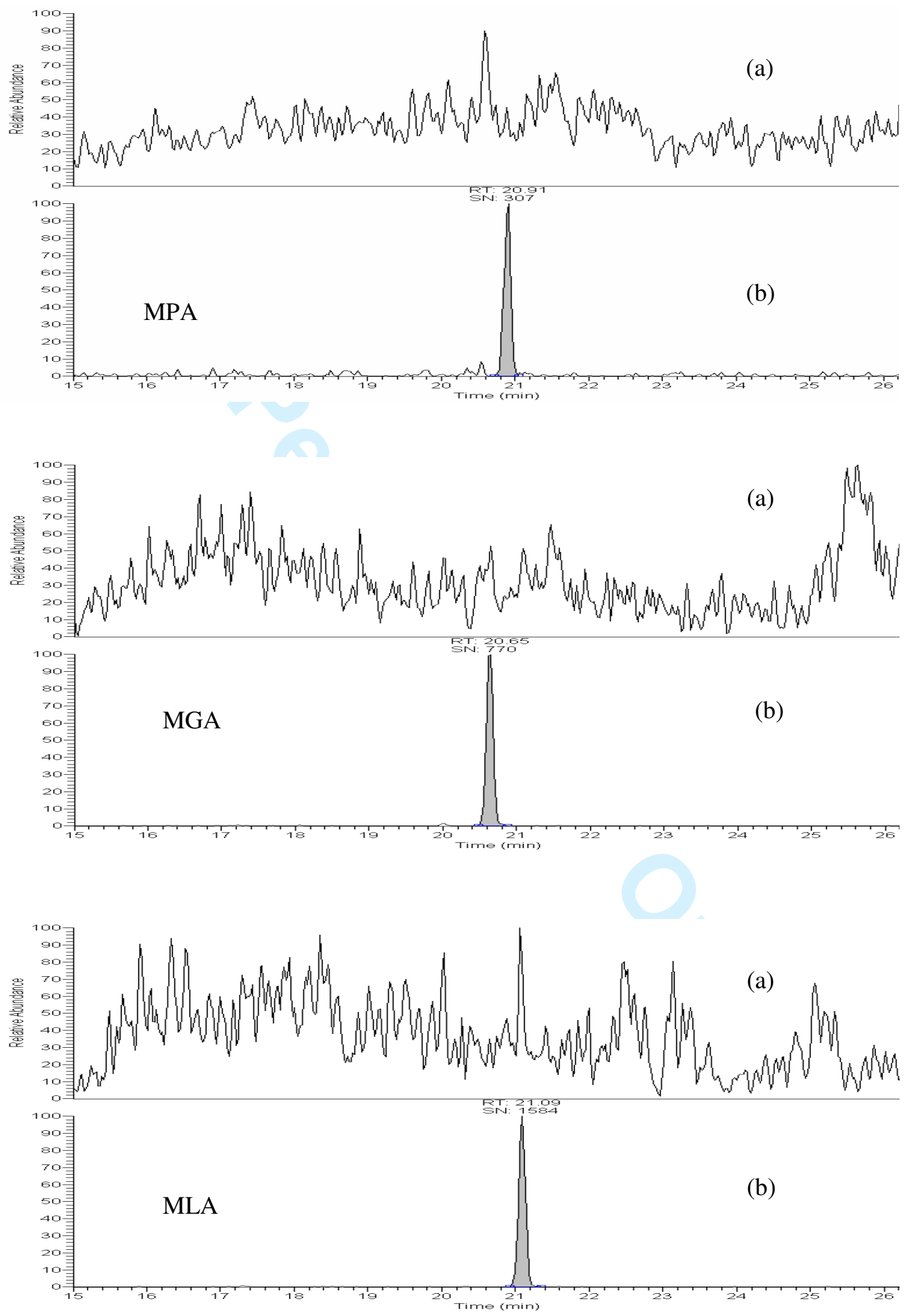

http://mc.manuscriptcentral.com/tfac Email: fac@tandf.co.uk 

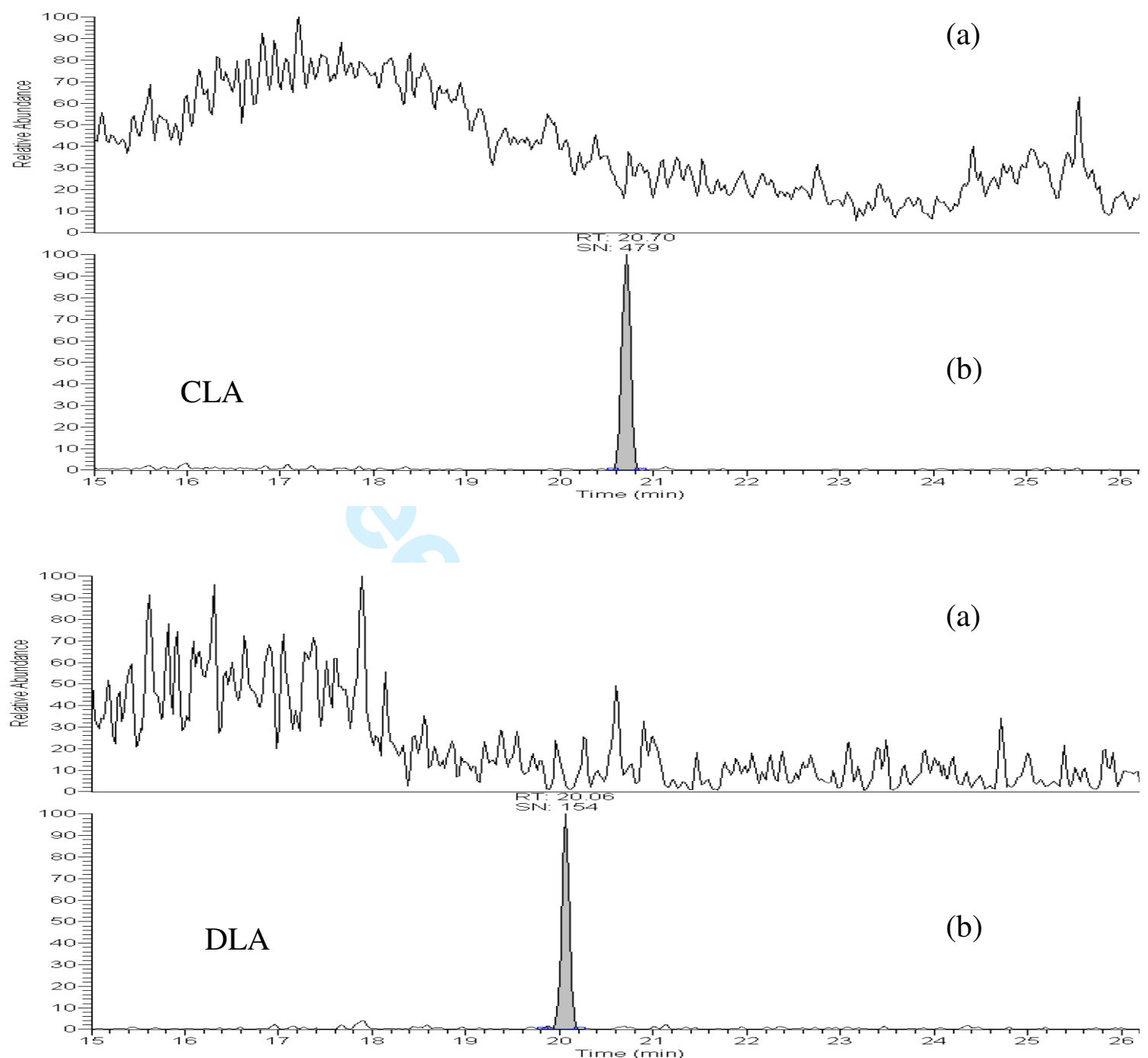

Figure 1. (a) Negative control kidney fat (b) Kidney fat fortified with $0.5 \mu \mathrm{g} \mathrm{kg}^{-1}$ MPA and $2.5 \mu \mathrm{g} \mathrm{kg}^{-1}$ of MGA, MLA, CLA and DLA respectively. 

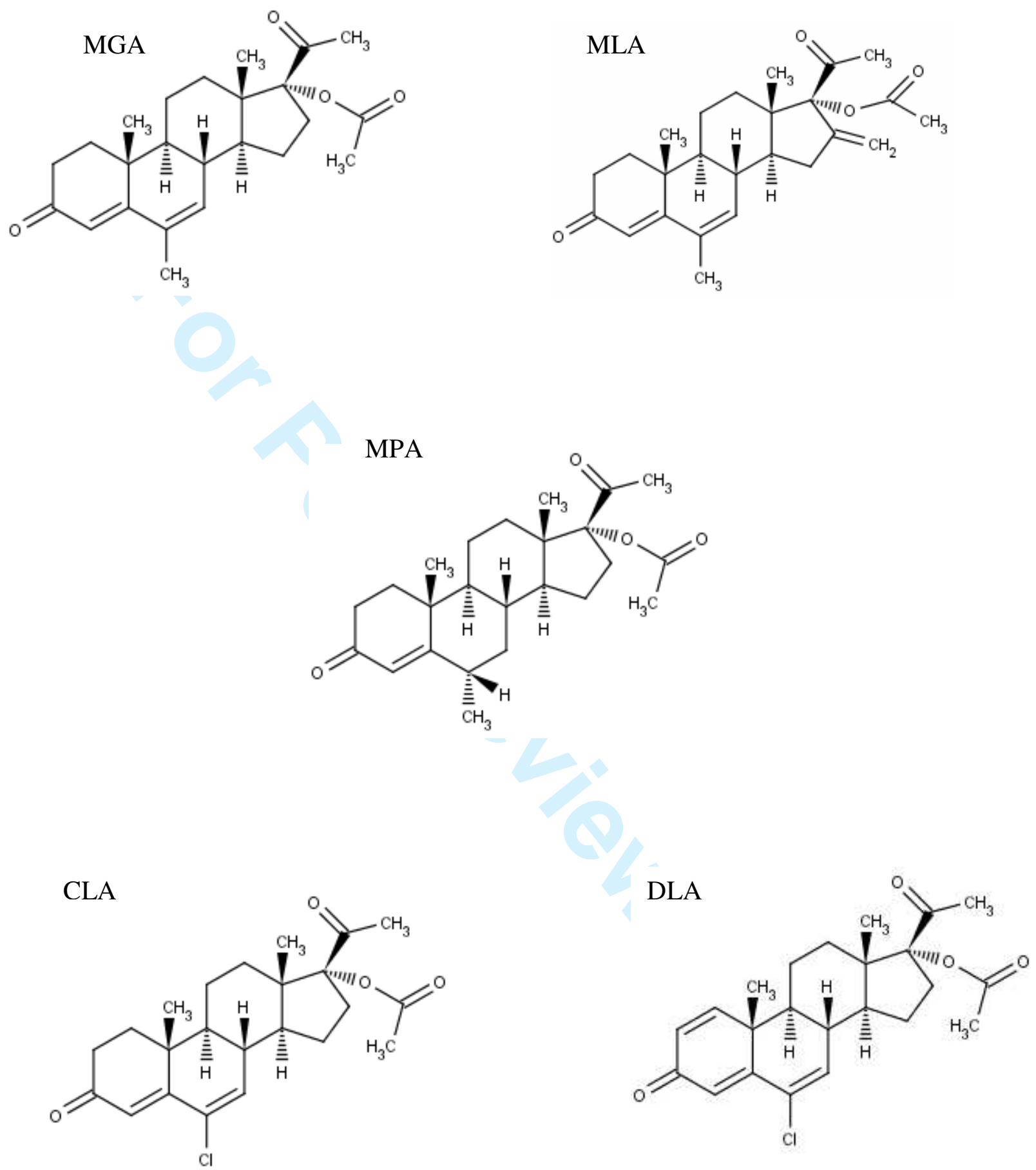

Figure 2. Structures of the various acetylgestagen compounds 

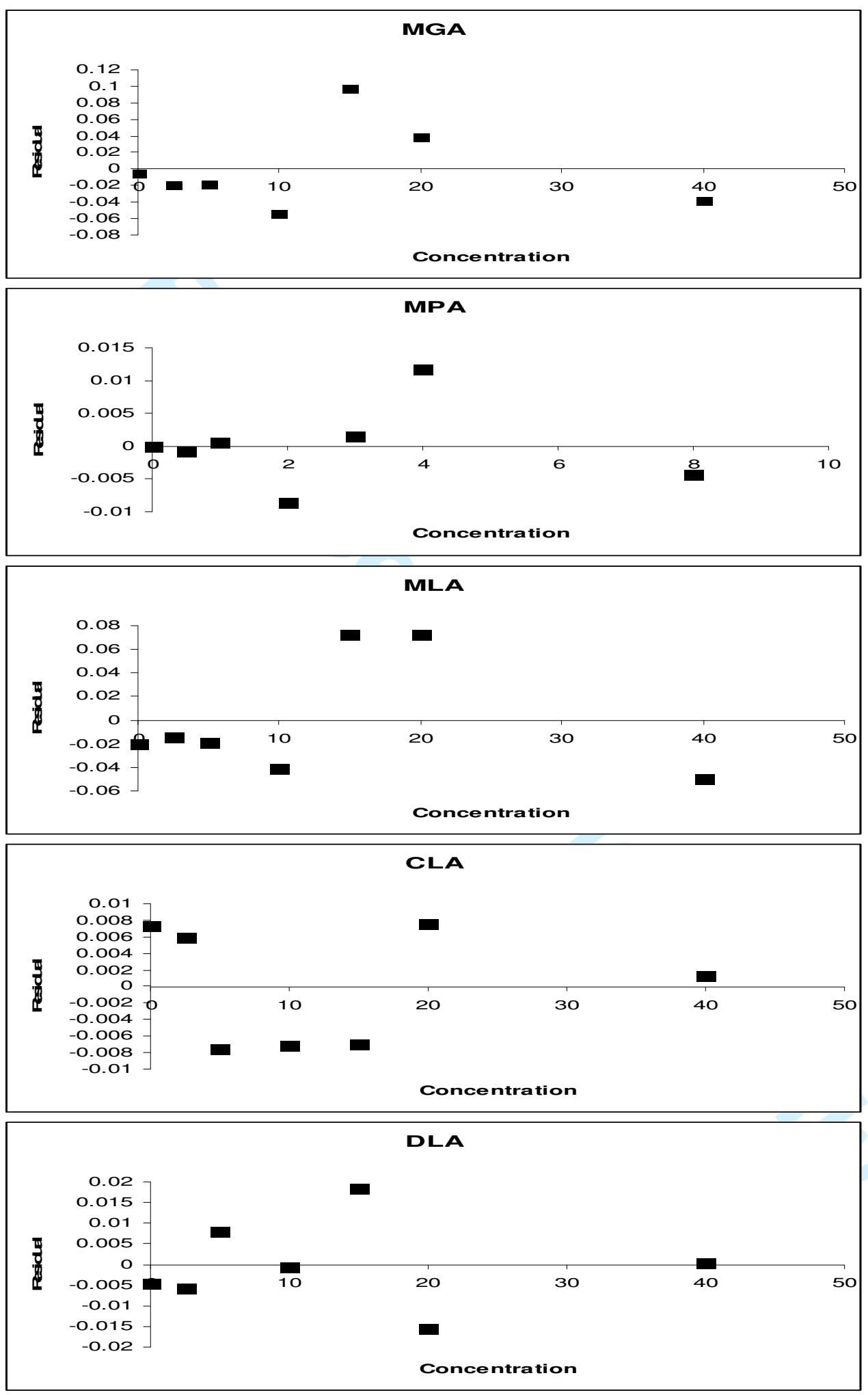

Figure 3. Plot of residuals for each acetylgestagen compound, concentration is $\mu \mathrm{g} \mathrm{kg}^{-1}$ in each case. 


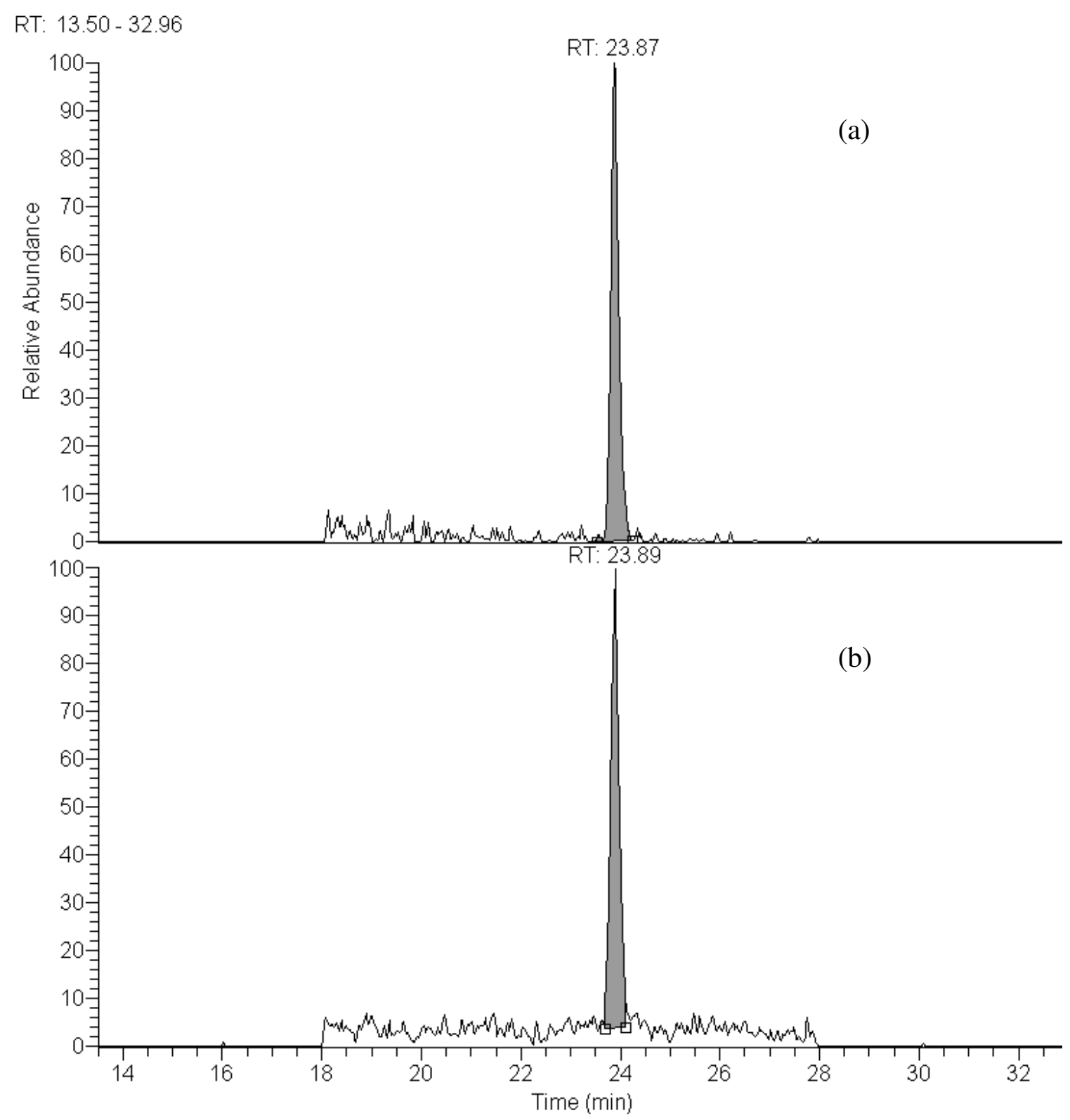

Figure 4. Incurred sample of kidney fat at a concentration of $1.2 \mu \mathrm{g} \mathrm{kg}{ }^{-1}$. (a) Strong Transition (m/z) 387.0>327.2 and (b) Weak Transition (m/z) 387.0>285.2 
Table 1: LC gradient profile for determination of MPA, MGA, MLA, DLA and CMA.

\begin{tabular}{ccc}
\hline $\begin{array}{c}\text { Time } \\
(\mathrm{min})\end{array}$ & $\begin{array}{c}\text { Component A } \\
(\%)\end{array}$ & $\begin{array}{c}\text { Component B } \\
(\%)\end{array}$ \\
\hline 0 & 90 & 10 \\
6.5 & 90 & 10 \\
10.0 & 35 & 65 \\
20.0 & 35 & 65 \\
22.5 & 90 & 10 \\
28.0 & 90 & 10 \\
\hline
\end{tabular}

Component A: $\quad 0.5 \mathrm{mM}$ ammonium acetate buffer + methanol (70:30, v/v).

Component B: $\quad 0.5 \mathrm{mM}$ ammonium acetate buffer + methanol (5:95, v/v). 
Table 2: MS/MS parameters for determination of each of the investigated analytes and their associated deuterated analogues.

\begin{tabular}{|c|c|c|c|c|}
\hline Compound & $\begin{array}{c}\text { Transition } \\
(\mathrm{m} / \mathrm{z})\end{array}$ & Polarity & $\begin{array}{c}\text { Collision } \\
\text { Energy }(\mathrm{eV})\end{array}$ & $\begin{array}{c}\text { Retention } \\
\text { Time (min) }\end{array}$ \\
\hline \multirow{2}{*}{$\begin{array}{c}\text { Medroxyprogesterone } \\
\text { Acetate }\end{array}$} & $387.0>327.2 *$ & \multirow{2}{*}{ Positive } & 15 & \multirow{2}{*}{18.5} \\
\hline & $387.0>285.2$ & & 18 & \\
\hline \multirow{2}{*}{$\begin{array}{l}\text { Megestrol } \\
\text { Acetate }\end{array}$} & $385.3>325.1^{*}$ & \multirow{2}{*}{ Positive } & 19 & \multirow{2}{*}{18.2} \\
\hline & $385.3>267.3$ & & 15 & \\
\hline \multirow{2}{*}{$\begin{array}{l}\text { Melengestrol } \\
\text { Acetate }\end{array}$} & $397.3>337.3^{*}$ & \multirow{2}{*}{ Positive } & 20 & \multirow{2}{*}{18.6} \\
\hline & $397.3>279.2$ & & 15 & \\
\hline \multirow{2}{*}{$\begin{array}{l}\text { Delmadinone } \\
\text { Acetate }\end{array}$} & $403.2>205.1 *$ & \multirow{2}{*}{ Positive } & 19 & \multirow{2}{*}{17.7} \\
\hline & $403.2>181.1$ & & 21 & \\
\hline \multirow{2}{*}{$\begin{array}{l}\text { Chlormadinone } \\
\text { Acetate }\end{array}$} & $405.0>308.9 *$ & \multirow{2}{*}{ Positive } & 17 & \multirow{2}{*}{18.3} \\
\hline & $405.0>344.9$ & & 13 & \\
\hline $\begin{array}{l}\text { Medroxyprogesterone } \\
\text { Acetate-d3 }\end{array}$ & $390.0>330.2$ & Positive & 15 & 18.4 \\
\hline $\begin{array}{l}\text { Megestrol } \\
\text { Acetate-d3 }\end{array}$ & $388.3>328.2$ & Positive & 15 & 18.2 \\
\hline $\begin{array}{l}\text { Melengestrol } \\
\text { Acetate-d3 }\end{array}$ & $400.2>340.2$ & Positive & 15 & 18.6 \\
\hline
\end{tabular}

* Denotes strong transition 
Table 3: CC $\alpha$, CC $\beta$, Within-laboratory Reproducibility RSD (\%), Accuracy (\%) and Measurement of Uncertainty (\%) for each analyte.

\begin{tabular}{|c|c|c|c|c|c|}
\hline Compound & $\begin{array}{c}\mathrm{CC \alpha} \\
\left(\mu \mathrm{g} \mathrm{kg}^{-1}\right)\end{array}$ & $\begin{array}{c}C C \beta \\
\left(\mu \mathrm{g} \mathrm{kg}^{-1}\right)\end{array}$ & $\begin{array}{c}\text { RSD } \\
(\%)\end{array}$ & $\begin{array}{c}\text { Measurement } \\
\text { of Uncertainty } \\
(\%)\end{array}$ & $\begin{array}{c}\text { Accuracy } \\
(\%)\end{array}$ \\
\hline $\begin{array}{c}\text { Medroxyprogesterone } \\
\text { Acetate }\end{array}$ & 0.12 & 0.20 & 4.4 & 16 & 99.8 \\
\hline $\begin{array}{l}\text { Megestrol } \\
\text { Acetate }\end{array}$ & 0.48 & 0.81 & 5.2 & 16 & 99.1 \\
\hline $\begin{array}{l}\text { Melengestrol } \\
\text { Acetate }\end{array}$ & 0.40 & 0.68 & 4.2 & 18 & 98.4 \\
\hline $\begin{array}{l}\text { Delmadinone } \\
\text { Acetate }\end{array}$ & 0.63 & 1.07 & 4.7 & 26 & 98.4 \\
\hline $\begin{array}{l}\text { Chlormadinone } \\
\text { Acetate }\end{array}$ & 0.54 & 0.92 & 4.4 & 26 & 98.4 \\
\hline
\end{tabular}

